\title{
The Digital Promotion Strategy of Tourism Sector Towards Sustainable Tourism Development
}

\author{
Erna Susanti*, Deni Amelia \\ Prodi Sistem Informasi \\ Universitas Putra Indonesia YPTK \\ Padang, Indonesia \\ *ernasusan77@gmail.com, deniamelia10@gmail.com
}

\begin{abstract}
The development of technology and communication is rapidly increased. It is in line with the increasing number of internet users in the world. This gives opportunities for business people to market their business online, as well as the opportunity for the government to promote its strategic sectors, one of them is the tourism sector. This study is aimed to determine the digital promotion strategy of the tourism sector in Padang City. This research is a descriptive qualitative research using triangulation method as the data collection which includes the observation method, the survey method and the literature study method simultaneously. The sampling technique used was purpose sampling. The results showed that the digital promotion strategy used by Padang city government was websites and social media in form of Instagram and Facebook that was attractive and well packaged. The digital promotion strategy by social media is aimeed to introduce the tourism of Padang City to the world. By having wider reach of tourism information, it is expected to increase tourist visits, both domestic tourists and international tourists. This will contribute a positive impact on the economy and social culture of the community.
\end{abstract}

Keyword-strategy, promotion, digital, tourism, sustainable development

\section{INTRODUCTION}

The development of information and communication technology (ICT) is growing rapidly. It is in line with the increasing number of internet users around the world including in Indonesia. From the Indonesian Internet Penetration and Behavior Survey in 2017 by the Indonesian Internet Service Providers Association (APJII) released in February 2018, it was stated that in 2017, the number of internet users in Indonesia reached 143.26 million people [1]. By this significant number, Indonesia was placed as the 5th country that has the most internet users in the world. Data released by Internet World Stats as of December 31 st in 2017, stated that the 1st to 4th ranks were China, India, the United States and Brazil [2]. With the large number of information technology users in Indonesia, this is certainly a great opportunity for people who have business to market their business online. Not left behind, the government also has opportunity to provide information and promote its strategic sectors such as in tourism sector. Technological progress is somewhat inevitable, all sectors must face it with new spirit and enthusiasm in the digital world. Innovation must be developed continuously to answer the challenges and opportunities in this digital era. Nowadays, tourists have taken advantage of online technology. For this reason, tourism can no longer be cultivated by solely relying on conventional methods. So that, a transformation from conventional to digital is needed. There are several social media that can be used to disseminate information such as the use of websites, blogs and social media like Facebook, Instagram, Twitter and similar applications. These accounts can be accessed easily through computers, smart phones and tablets which have become part of today's society.

Many social media users use their accounts to spread information about their travels. These social media users then become a reference for the public regarding interesting places through their writing and reportage on their social media. Social media readers or well-known as netizen are greatly helped and interactions often occur between account owners and readers in cyberspace. Social media represent a key touchpoint in the traveller customer journey. Specifically, in pre purchase phase, social media a source of inspiration for traveller; during the hotel stay, these platform are used by traveller to share thr experient in the realtime with their community; finally, in the post purchase phase, traveller can write review in social media or keep in sharing their experience with other user, thus favouring e-WOM [3].

Social media may serve as a channel for many marketing activities including promotion, sales and customer services. Hospitality and tourism companies and organization should formulate their brand strategy in social media differently and according to the industry they belong to, as the existing range of platform seem to plays distinct role [4]. The destination manager and other tourism business should optimize social media marketing effort to facilitate a co-creational process of destination communication by encouraging traveler to consume content and share their experience on socal media before, during and after they visit. Providing a platform for tourist to have a meaningful interpretation of the social context of the destination could result in a memorable unique acculturating experience in the mind of the tourist [5]. Social media marketing activities indirectly affect satisfaction 
through social identification and perceived value. At the same time, social identification and perceived value directly affect satisfaction that then influences continuance intention, participation intention and purchase intention [6].

The development of communication and information technology (ICT) cannot be separated from people's lifes in this digital era. ICT plays an important role in various aspects of human life. In the past, information was easily accessible using printed and electronic mass media such as newspapers, magazines, television, radio, etc. Along with the times, ICT has shifted to internet-based media. The internet makes it easy to share information widely through social media and can also be accessed anytime and anywhere. Furthermore, the use of internet-based social media makes information providers and recipients closer together. Presently, social media marketing was necessary, social media marketing scope represents a range from defenders to explorers, social media marketing culture includes the poles of conservatism and modernism, social media marketing structures fall between hierarchies and networks, and social media marketing governance ranges from autocracy to anarchy [7].

Based on the regulation of the Government of the Republic of Indonesia No. 50 Year 2011 concerning the National Tourism Development Master Plan 2010-2025, the tourism area of Padang City is included in 222 (Two Hundred Twenty Two) National Tourism Development Zones (KPPN) in 50 national tourism destinations. This is in line with the vision of the development of Padang City in the next five years: Realizing Padang as a City of Education, Trade and Tourism that is Prosperous, Religious, and Cultural.

Based on data obtained from Padang City Central Bureau of Statistics, a positive trend can be seen in the increasing of foreign and domestic tourists visiting from 2013 - 2016 [8], as illustrated in table 1 below:

TABLE I. THE NUMBER OF FOREIGN AND DOMESTIC TOURISTS IN PADANG 2013 - 2016

\begin{tabular}{|l|l|l|l|l|}
\hline \multicolumn{1}{|c|}{ Tourist } & \multicolumn{4}{c|}{ Amount of Foreign and domestic tourism } \\
\hline & 2013 & 2014 & 2015 & 2016 \\
\hline Foreign & 53,067 & 54,967 & 57,318 & 45,194 \\
\hline Domestic & $3,001,306$ & $3,199,392$ & $3,298,454$ & $3,628,299$ \\
\hline Total & $3,054,364$ & $3,254,359$ & $3,355,772$ & $3,673,493$ \\
\hline
\end{tabular}

The increase in the number of tourists, both foreign and domestic, has revived other economic sectors, including the increase in hotel accommodation facilities from various hotel classifications, as in the table 2 below:
TABLE II. NUMBER OF HOTEL ACCOMODATIONS BY HOTEL ClassificATION in PADANG 2013-2016

\begin{tabular}{|l|l|l|l|l|}
\hline \multicolumn{1}{|c|}{ Hotel Level } & \multicolumn{1}{|c|}{$\mathbf{2 0 1 3}$} & $\mathbf{2 0 1 4}$ & \multicolumn{1}{c|}{$\mathbf{2 0 1 5}$} & $\mathbf{2 0 1 6}$ \\
\hline Five Stars & 1 & 1 & 1 & 1 \\
\hline Four Stars & 2 & 3 & 3 & 5 \\
\hline Three Stars & 5 & 5 & 5 & 6 \\
\hline Two Stars & 5 & 5 & 5 & 9 \\
\hline One Star & 2 & 2 & 12 & 5 \\
\hline Inn/ Motel & 55 & 56 & 76 & 62 \\
\hline
\end{tabular}

Currently, tourism development is directed towards sustainable tourism development because sustainable tourism development policies are directed at developing natural resources and the use of human resources for a long term. Sustainable tourism development refers to the environmental, economic and social aspects of a tourist destination.

Sustainable tourism development strategies and management practices are relevant to all systems of tourism in all categories of destinations with mass tourism and the various niche tourism sectors. Sustainability values refer to the environmental, economic, and socio-cultural parts of tourism development, and a suitable balance must be established between these three dimensions to guarantee its long-term sustainability.

Sustainable tourism development needs the informed contributions of all related stakeholders, as well as strong political leadership to ensure wide participation and consensus building. Achieving sustainable tourism is a continuous process and it requires constant monitoring of impacts, introducing the necessary preventive and/or corrective measures. The private-sector is critical in legitimizing tourism and hospitality development through addressing sustainability aims [9]. it is necessary educate participants related to the development of tourism and monitor the outcomes of the implementation of tourism-related development in the spirit of sustainable development principles [10]. The residents' perceptions differed across the developmental stages; thus, managers should consider the development opportunities and adopt appropriate strategies across different development stages [11].

\section{METHODOLOGY}

This research is a qualitative research with a descriptive research design using triangulation techniques by following the data with the observation method, in-depth interviews and documentation carried out simultaneously to the actors / stakeholders of tourism in Padang City. The sampling technique used was purpose sampling, The data collected form the stakeholders of tourism in Padang City which consists of the Tourism Office, PHRI, Community and NGOs.

\section{RESULTS AND DISCUSSION}

\section{A. Results}

Digital promotion strategy used by Padang City Government was website and social media. Social media 
platforms used were Instagram and Facebook. These social media gave information about destinations, shopping centres, attraction events, culinary and local cultures.

The digital promotion strategy by social media is aimeed to introduce the tourism of Padang City to the world. By having wider reach of tourism information, it is expected to increase tourist visits, both domestic tourists and international tourists. This will contribute a positive impact on the economy and social culture of the community.

\section{B. Discussion}

Social medial used by Padang Government to promote Padang tourism and culture, as follow:

1) Website. The website of Padang City can be visited at tourism.padang.go.id which provides complete information about Padang City. The information available on the website are city profiles, tourist destinations, events \& culture, culinary \& shopping, about Padang and publications (see figure 1).

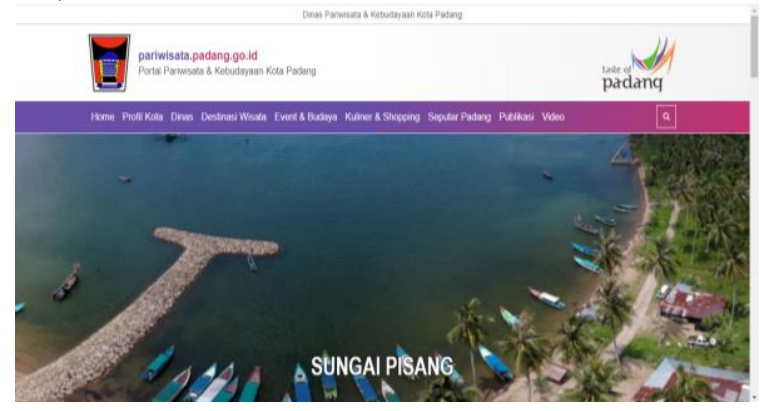

Fig. 1. Website of the culture and tourism office.

2) Instagram. The Instagram of the Padang City Tourism and Culture Office is created to promote tourism and culture of Padang City to local, national and international communities. With the creation of this Instagram, it is hoped that all tourism activities and information can be known by all followers of this social media.

This social media provides information on tourism activities in Padang City, in form of ongoing events, tourist objects, traditions and traditional arts and other tourism information (see figure 2).

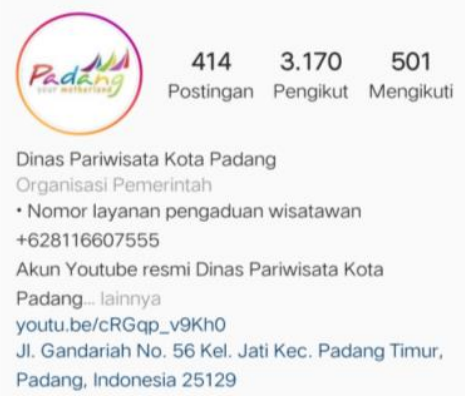

Fig. 2. Instagram of Padang city culture and tourism office.
3) Facebook. This social media provides information about tourist destinations, reviews of the creative industry in Padang City, traditions and traditional arts, tourism events and tourism information of Padang City (see figure 3).
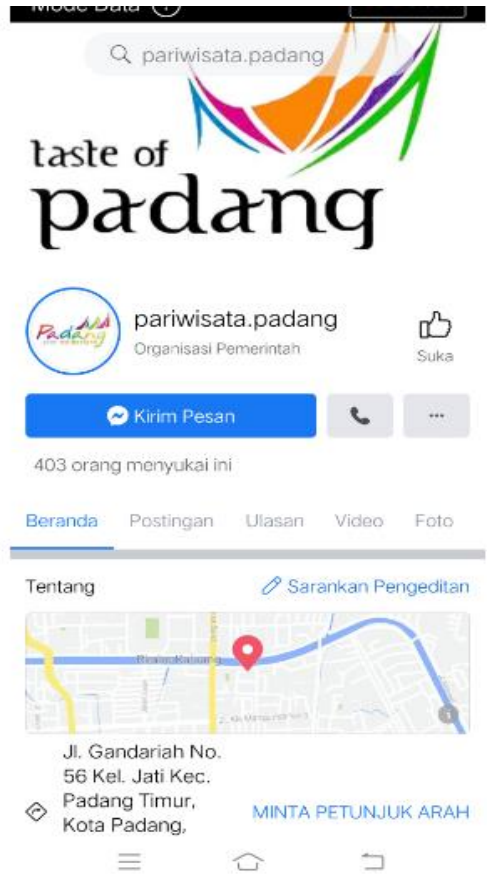

Fig. 3. Social media Facebook of the Padang city culture \& tourism office.

\section{CONCLUSION}

Based on the results of observations and surveys in the field and literature studies that have been carried out, the following conclusions are obtained: Padang City Government uses a digital promotion strategy to promote the tourism sector, the digital promotion strategy used is a website/ portal and social media in form of Instagram and Facebook. The website and social media used are designed to be attractively packaged and provide various information about tourism and culture of Padang City. The digital promotion strategy by social media is aimeed to introduce the tourism of Padang City to the world. By having wider reach of tourism information, it is expected to increase tourist visits, both domestic tourists and international tourists. This will contribute a positive impact on the economy and social culture of the community

\section{ACKNOWLEDGMENT}

This reserach is fully funded by Universitas Putra Indonesia YPTK Padang.

\section{REFERENCES}

[1] I. internet service Assosiation, "survey APJII," Jakarta, 2018.

[2] Internet world stat, "internet world stat," www.internetoworldstat, 2018. 
[3] L. Hu and M. Olivieri, "Social media management in the traveller's customer journey: an analysis of the hospitality sector," Curr. Issues Tour., vol. 0, no. $0, \quad$ pp. 1-12, 2020, doi: 10.1080/13683500.2020.1819969.

[4] S. Moro and P. Rita, "Brand strategies in social media in hospitality and tourism,” Int. J. Contemp. Hosp. Manag., vol. 30, no. 1, pp. 343-364, 2018, doi: 10.1108/IJCHM-07-2016-0340.

[5] C. Li, S. Guo, C. L. Wang, and J. Zhang, "Veni, vidi, vici: The impact of social media on virtual acculturation in tourism context," Technol. Forecast. Soc. Change, 2019, doi: 10.1016/j.techfore.2019.01.013.

[6] S. C. Chen and C. P. Lin, "Understanding the effect of social media marketing activities: The mediation of social identification, perceived value, and satisfaction," Technol. Forecast. Soc. Change, vol. 140, no. July 2018, pp. 22-32, 2019, doi: 10.1016/j.techfore.2018.11.025.
[7] R. Felix, P. A. Rauschnabel, and C. Hinsch, "Elements of strategic social media marketing: A holistic framework," J. Bus. Res., vol. 70, 2017, doi: 10.1016/j.jbusres.2016.05.001.

[8] Unknown. [Online] Retrieved at: www.bpspdg.go.id, "local bereau Stat," 2017.

[9] N. MacKenzie and M. J. Gannon, "Exploring the antecedents of sustainable tourism development," Int. J. Contemp. Hosp. Manag., vol. 31, no. 6, pp. 2411-2427, 2019, doi: 10.1108/IJCHM-05-2018-0384.

[10] I. Kapera, "Sustainable tourism development efforts by local governments in Poland," Sustain. Cities Soc., vol. 40, pp. 581-588, 2018, doi: 10.1016/j.scs.2018.05.001.

[11] T. H. Lee and F. H. Jan, "Can community-based tourism contribute to sustainable development? Evidence from residents' perceptions of the sustainability," Tour. Manag., vol. 70, no. September 2018, pp. 368 380, 2019, doi: 10.1016/j.tourman.2018.09.003. 